\title{
Mobile Assisted Language Learning for Developing Students' Attitudes
}

By

\author{
Nada Fathy Mohamed kener \\ Demonstrator in Curriculum and Instruction Department
}

\section{Dr. El Sayed Mohamad Dadour}

Professor of Curriculum \& TEFL \& Vice President for community services and environment development affairs

Damietta University

\section{Dr/ Hanaa El-Baz El-Sayed Ibrahim}

Lecturer of Curriculum \& TEFL,

Damietta University 
The wide spread and rapid constant development of mobile phones with all its capabilities has opened up numerous opportunities for its integration into learning. Thus, the term mobile assisted language learning (MALL) appears to describe an approach that uses mobile devices to facilitate language learning and to make learning as ubiquitous as possible. The present study aims at investigating the effectiveness of a program based on MALL approach in developing second-year preparatory school students' attitudes toward writing. The study sample consists of sixty participants selected at random from two schools located in Damietta governorate and was divided into two groups: experimental $(\mathrm{N}=30)$ and a control $(\mathrm{N}=30)$. A pre-post attitude scale was applied on the subjects to compare their attitudes before and after implementing the experiment. The program was implemented on the experimental group for seven weeks using mobile phones while the control group was taught using the regular course and method of teaching. T-test results show that using MALL approach managed to significantly develop experimental group students' positive attitudes toward writing. The study offered suggestions for further studies. Results assert that using mobile phones increases students' enthusiasm and encourages them to write in English.

Key words: Mobile assisted language learning, attitudes, writing, and mobile phones

\section{Introduction}

This age is characterized by rapid change in all different life aspects. This change is a result of speedy development in the field of information and communication technologies (Tayebinik and Puteh, 2012). The traditional classroom and textbooks can no longer satisfy the needs of new generations of students who used to deal with technological tools since their childhood. Therefore, educational institutions have started to search for new educational methods to incorporate modern technology in the learning process (Moghaddam and Mousavi, 2012). In this digital era, the increasing prevalence of portable and wireless devices creates significant change in teaching and learning practices (Kukulska-Hulme, 2009). With the integration of mobile and portable technologies in learning, the term mobile learning, which gains increased interest in recent years, appears to support various kinds of learning (Kukulska-Hulme and Shield, 2008).

Mobile Assisted Language Learning (MALL) is seen to be one of the technology-based learning devices. Research (e.g. Abbasi and Hashemi, 2013; Abu Sa'aleek 2014; Kim and Kwon, 2012; Korkmaz, 2010; Kukulska-Hulme and Shield, 2008; Miangah and Nezarat, 2012; National Council for curriculum and Assessment, 2007) agrees that MALL is an approach to language learning that uses 
handheld mobile devices such as mobile phones, smartphones (including the iPhone or iPad), Personal Digital Assistants (PDAs), MP3 or MP4 players (e.g. iPods), tablet PCs, digital cameras, laptop computers to make learning as ubiquitous as possible. Gholami and Azarmi, (2012) perceive MALL as a language teaching methodology supporting e-learning features, while Pilar, Jorge and Cristina (2013) consider it as both a teaching and learning methodology. Other researchers characterize MALL by numerous learning forms including faceto face, distant, on-line, formal, informal, collaborative and individual learning modes within any context (Baleghizadeh \& Oladrostam, 2010; Haag \& Berking, 2015).

Kukulska-Hulme (2006) states that mobile learning is very important for learners in the current age. She believes that, it facilitates flexible communication with mobile devices without the need for resorting to traditional computers labs and/or classrooms. Also, it enhances collaborative learning through creating a virtual community and participating verbally, or in a written form, to perform tasks through online sites. In addition, she illustrates that today, with the increasing overload on teacher and the increasing number of students in a class; it is too difficult to provide feedback to students' writing. With the help of mobile technologies, it becomes easy for teachers to support quick feedback. In addition, mobile technologies and especially mobile phones increase learners' motivation and engagement into language learning. She claims that using mobile devices facilitates rapid delivery of up-to-date content for learners to access, receive and carry whenever and wherever they want.

Today, mobile learning becomes much easier through using mobile devices to deliver learning materials and/or content to learners (Khabiri and Khatibi, 2013). Miangah and Nezarat (2012) believe that these devices have been used as tools for education to make it as ubiquitous as possible for its users whether teachers or students. Nowadays, the expansion of wireless technology has created new numerous opportunities in language learning and teaching (AbuSa'aleek, 2013; Gholami and Azarmi, 2012; Oz, 2015; Yedla, 2013). Recently, mobile learning refers to gaining popularity as a means of transmitting educational information by means of handy technology devices such as mobile phones as they have more processing power and more attractive functional devices than more commonly obtainable desktop machines (Yedla, 2013: 92).

Gholami and Azarmi (2012) assert that mobile phones are widely spread among younger people; therefore curriculum developers are likely to incorporate them in educational environments. They state that they are favored for being less expensive and more available than their counterparts. Also, they support interaction through synchronous and asynchronous discussion using voice, text and multimedia besides delivering content. As these modern devices are integrated in 
language instruction, there are increasing opportunities for teachers and learners to be more globally associated and interacted $(\mathrm{Oz}, 2015)$. Gholami and Azarmi (2012) describe MALL as the ideal medium for language learners who travel, and for those who want to have fun by learning English. The use of mobile technology is a new gate-way to create more interactive environment in the classroom in an interesting and innovative way by making teaching more effective (Yedla, 2013).

Currently, there is a dire need to incorporate mobile technologies in language learning. Everybody carries a mobile which has the same functionalities, features and capabilities as computers. Miangah and Nezarat (2012) mention that mobile devices are easier and lighter to be carried than books. Mobile phones are considered the most available and familiar devices used to facilitate language learning. Nowadays, knowledge is multiplied rapidly, so the determinate human mind does not have the capacity to assimilate and remember the increasing amount of knowledge. Kim and Kwon (2012) claim that storage capacities of smart phones nowadays are increasing to the extent that they can store a big number of materials which learners can use and access at any time everywhere. Recent studies in teaching EFL prove the effectiveness of mobile phones in teaching language skills as well as aspects (e.g. Ally, McGreal, Schafer, Tin \& Cheung 2007; Azar \& Nasiri 2014; Baleghizadeh \& Oladrostam, 2010; kennedy \& levy 2008; Thornton \& Houser, 2005).

Also, research proves that students have favorable perceptions about using phones in learning. The study of Leis, Tohei and Cooke (2015) proves that the use of smartphones increases learners' intrinsic motivation to learn and develop their independence. Moreover, the survey conducted by Averianova (2012) proves university students' positive attitudes toward using phones in language learning as well as their readiness to employ phones in learning. Thus, research (e.g. Azar \& Nasiri 2014; kennedy \& levy 2008; Thornton \& Houser, 2005) indicates that the use of mobile in language classes establish an interesting and attractive classroom environment. They showed the necessity to break the routine of traditional classroom interaction that does not suit the tempo of the age of technology. Therefore, mobile phones are favorable tools for teaching writing as a life skill.

Furthermore, several studies recommend using technology to develop students' inclination toward learning writing skills. Several studies suggest using celluar phones in educational settings for improving the quality of learning, facilitating the mastery on both receptive and productive language skills, and helping the reluctant students be more motivated and more focused for longer periods of language learning (Al Amari \& Suleiman 2011; Azar \& Nasiri 2014; Baleghizadeh \& Oladrostam 2010; Kennedy \& Levy 2008; Moghaddam \& Mousavi, 2012;). 
Nowadays, social media and mobile chatting have caused collapse in grammar and writing. Younger learners are using wrong spelling and confusing messy sentences to express their feelings and ideas without receiving a corrective feedback. Elashri (2013) and Salama and Al-Ashiri (2012) state that students have negative attitudes toward writing. As learners have positive perceptions toward mobile phones, the current research attempts to investigate how far mobile phones may develop their positive feelings toward writing.

\subsection{Background and statement of the problem}

Research proves that students are not motivated to write and they consider writing as the most boring activity in any language class. Elashri (2013), in addition to Salama and Al-Ashiri (2012), state that students are weak in writing skills, so they have negative attitudes toward writing. Alsayed (2014) states that writing attitudes affect writing achievement, so students with a more positive attitude will write more often than those with a more negative attitude. Penaflorida (2002) indicates that learners have a negative attitude toward writing especially after occasions of previous failure. According to students' positive or negative attitudes toward writing and their views concerning their writing ability, they decide to write or stop being engaged in writing tasks.

Furthermore, several studies recommend using technology to develop writing skills. For example, Thornton and Houser (2005) recommend using mobile devices for taking notes, writing essays and reports. Several studies suggest using cellular phones in educational setting for improving the quality of learning, facilitating the mastery on both receptive and productive language skills and helping the reluctant students be more motivated and more focused for longer periods in language learning (Al Amari \& Suleiman 2011; Azar \& Nasiri 2014; Baleghizadeh \& Oladrostam 2010; Kennedy \& Levy 2008; Moghaddam \& Mousavi, 2012;).

The present researchers conducted a pilot study for the sake of identifying how far preparatory school students were willing to make use of mobile phones in learning English. The pilot sample included 100 second-year, male and female, students. The results of such a pilot study revealed that $78 \%$ of the students agreed on the suggestion of utilizing mobiles in their English classes. The results, also, indicated that they thought that the use of mobiles could make them more enthusiastic during learning process and improve their attitudes toward classroom tasks; especially writing tasks.

The problem of the study can be summed up in students' negative attitudes toward writing tasks which affect their classroom writing performances. While traditional methods of teaching writing may not help in solving such a problem, a 
new approach of teaching may help students enjoy writing tasks more. Hence, the present study seeks to find out how far a proposed program based on MALL approach can enhance preparatory school students' attitude toward writing tasks.

Thus, the present research tries to answer the following questions:

1- What are second year preparatory school students' attitudes toward writing?

2- What are the specifications of a proposed writing program designed on the basis of MALL?

3-To what extent will the proposed program develop preparatory school students' attitude toward writing?

\section{Review of literature:}

\subsection{Mobile learning:}

Ally, McGreal, Schafer, Tin and Cheung (2007) prepared a project to help post-secondary students and other adults who needed assistance with remedial interactive grammar lessons and exercises using mobile phones. These students found that it was a positive experience to learn grammar using mobile phones. They thought that true/false and multiple choice-type questions were more suitable for mobile devices.

Similarly, Lu (2008) explored the role of SMS in enhancing high school students' vocabulary learning. A sample of 30 students was divided into two groups; the first group received the first 14 target words via mobile SMS, while the other group learned the same vocabulary using the ordinary method. After a week, the two groups exchanged ways of learning vocabulary. The results indicated that the mobile phone groups have greater vocabulary achievements than their paperpencil counterparts. Also, those learners viewed that using mobile phones in vocabulary learning is enjoyable and helped them memorize vocabulary more easily.

Saran, Seferoglu and Cagiltay's (2008) study aimed at investigating the effect of mobile phones' multimedia messages (MMS) on improving Turkish university students' pronunciation of words. Twenty difficultly pronounced words taken from regular classroom instruction were sent to the students during lecture breaks on school days. The results demonstrated that the students who received multimedia messages studied supplementary materials more than other students. This frequent exposure to learning materials helped them to improve pronunciation of words.

Baleghizadeh and Oladrostam (2010) asserted the efficiency of MALL in improving grammatical accuracy of EFL students. They exploited mobile phones to review and practice certain grammatical forms to show their effect on students' speaking. Students recorded their voice on their mobile phones, then, out of class 
assignment, they analyzed their spoken mistakes and commented on them in subsequent class. The results of the study showed that the students had better performance on grammar tests and their grammatical skills were improved. Moreover, mobile phones managed to improve the speaking quality.

Alemi, Sarab and Lari (2012) used mobile devices to improve undergraduate ESL students' English academic writing. They designed an application called Grammar Clinic; a series of outside - class grammar exercises in the form of level error identification and correction to be used on mobile devices (PDA, smart phones and tablets). The ESL academic writing class in that study followed the process approach: writing the first draft followed by using three assignments of Grammar Clinic then second draft and finally peer review. Grammar Clinic had a positive effect on the students' writing development and reduction of errors in final drafts of paper assignments.

Abbasi and Hashemi's (2013) study aimed at identify the effect of using mobile phones on learners' vocabulary retention. A total number of 111 students studying in grade three of Iranian high school were divided into four groups: male and female experimental groups and the same for control groups. The control groups received paper-pencil activities to do out of the classroom; whereas the experimental groups received the same activities via their mobile phones using SMS. The findings proved that vocabulary retention in the experimental group was better than that in the control group. Therefore, it can be concluded that using mobile phones by high school EFL learners had a considerable effect on their vocabulary retention.

Alzu'bi and Sabha (2013) explored the role of mobile-based email in improving Jordanian English University students' achievement in writing and vocabulary. The two experimental groups were taught using a mobile-based email for three months. The results of the survey revealed that using the mobile-based email had a distinctive positive influence on improving the experimental groups' writing skills and improving their syntactic complexity, spelling, punctuation, and grammatical accuracy. Also, mobile phone e-mail increases the learners' motivation to learn as they can store e-mail messages to be used anytime and anywhere.

Furthermore, Sirinat, Sirorat, Suriya and Thooptong (2012) attempted to investigate the influence of text messages on secondary school students' English writing skills. It was found out that teaching English writing activities by the use of text messages via mobile phones developed the students' writing skill in spelling and grammatical structure. In addition, the text messages increased their enthusiasm to learn English as well as developing their positive attitude toward English writing. 
A survey of teachers conducted by Purcell, Buchanan and Friedrich (2013) proved that cellular phones are influential technological tools in teaching writing to middle and high school students. They facilitated pupils' personal expression and creativity; encouraged greater collaboration among them as well as encouraging them to write more often in more formats than ever have been.

Azar and Nasiri (2014) investigated the effectiveness of cellular phones on listening comprehension among EFL learners in Iran. The study compared cellular phones audio books to CD - ROM and audio cassette based audiobooks. The students who used cell phones exceeded their peers who used CD - ROM and audio cassette in listening comprehension. The students were motivated to learn considering cell phones useful learning tools with which they could exchange meaning with teachers and peers.

A study by Suwantarathip and Orawiwatnakul (2015) aimed at examining the effects of mobile-assisted vocabulary exercises on first-year university vocabulary acquisition. The sample was divided into experimental and control groups. Experimental group students completed vocabulary exercises via SMS while those of the control group did paper-based exercises in class. Experimental group students were required to receive activities via SMS and then send the answers from their mobile phones to the teacher to receive necessary feedback. The findings revealed that the students of the experimental group outperformed the control group in vocabulary post-test. They used and learned target vocabulary better than those in the control group.

Hammam (2017) investigated the effectiveness of a Mobile Assisted Language Learning (MALL) Program for developing some speaking skills of firstyear secondary school students. That researcher designed some speaking applications based on MALL and used them in teaching the participants. A pre and post oral speaking test was implemented to measure the differences between the performance of the participants before and after the experiment. Also, it was used to measure the differences in each domain of the five domains of speaking skills (comprehension, pronunciation, fluency, grammar, and vocabulary) for the experimental group in the post test. The findings showed that there were significant differences in participants' performance before and after implementing MALL in favor of the post-performance. That study recommended that teachers are asked to use MALL applications in EFL teaching to develop their students' speaking skills.

\subsection{Attitude}

Research on language attitudes illustrates that attitudes facilitate language learning and influence learners' performance in acquiring a target language. Alsayed (2014) states that writing attitudes affect writing achievement, so students 
with a more positive attitude will write more often than those with a more negative attitude. Also, Elashri (2013) illustrates that students who display low attitude scores toward writing display low writing performance and vice versa. Thus, research conducted on language teaching and learning seeks to investigate learners' attitudes toward language learning in general; and particularly toward writing. Several studies explore students' negative attitudes toward writing. For example, Clark and Dugdale (2009) as well as Salama and Al-Ashiri (2012) state that students are weak in writing skills, so they have negative attitudes toward writing. Ismail, Hussin and Darus (2012) indicate that students have negative attitude toward writing. They also state that English writing is difficult and tedious, so they dislike it. As a result, they do not have the interest to write or they may postpone completing writing tasks. In addition, they produce writings full of errors, cannot express their ideas well and fail to get a good grade.

A survey done by Clark and Dugdale (2009) revealed that young people agreed that writing is boring. Aydin and Başoz (2010) explored university English pre-service teachers' attitudes toward EFL writing. The findings revealed that female pre-service teachers had more positive attitudes toward writing when compared to males. In addition, the participants' proficiency levels were proven to be significantly correlated with their beliefs about writing. Moreover, the study of Erarslan (2011) revealed that the students' level of English was not a significant issue in their attitudes toward the writing course. Moreover, Kotula, Tivnan and Aguilar (2014) investigated the relationship between students' writing ability and their attitudes toward writing. Those researchers found that the students with low levels of writing achievement were able to write with quite few errors in grammar usage and mechanics. Moreover, the students with lower levels of writing achievement tended to rate their writing attitudes as more positive than their ratings of their own skills in writing. As a result, findings of that study support the relationship between student attitudes toward writing and writing performance.

In addition, the survey of Clark and Dugdale (2009) agreed with the study of Erarslan (2011) in the sense that girls hold more positive attitudes toward writing than boys. In addition, Ma'rouf and Nasser's (2010) study indicated that there is no difference between attitudes toward language and achievement. Also, the study of Saed and AL-Omari (2014) revealed no significant interaction between the method of instruction and students' general levels of English in students' writing achievement or attitudes toward writing.

As modern technology has become a basic part of our daily life and has been incorporated in the learning process, studies pursue to explore learners' attitudes toward using mobile learning phones in language learning. Kee and Samsudin (2014) state that participants' perceptions on the use of mobile device are the key factor that influences their decision in making use of the mobile 
devices to perform various types of activities. Azar and Nasiri (2014) investigate EFL learner's attitudes toward using cellular-phone based audiobooks to develop their listening comprehension. The results of their study concur with Al Fahd's study (2009) that participants acquired a positive attitude toward mobile phones as an interesting way to bring new opportunities for language learning. Furthermore, $\mathrm{Hu}$ (2011) indicates that the majority of the learners prefer learning vocabulary via mobile phones to the traditional way and their overall attitude toward it is very positive.

Similarly, the study of Al Amari (2011) shows that nearly $40 \%$ of university students hold a positive attitude toward using mobile phone in learning. Also, 34\% of participants agree that mobile phones enhance their motivation to learn. Rather, a survey conducted by Lin (2010) reveals that high school students are motivated to use mobile phones in learning because of their merits for facilitating learning English anywhere and making learning more fun. He explains that the owners of mobile phones who are more emotionally attached to their phones are more highly motivated to use them in their learning.

Findings of Averianova's (2012), Cavus and Ibrahim's (2009), Ibrahim's (2012) as well as Shanmugapriya and Tamilarasi's (2013) studies point out that students hold a highly positive attitude toward learning through mobile devices; since they are motivated to learn content which supports multimedia elements and gives them ubiquitous learning experience. Moreover, results of Cote, Milliner, Flowers and Ferreira's study (2014) reveal that 53\% of students prefer their mobile devices to a personal computer for language study. Moreover, Korkmaz's study (2010) asserts that the participants hold positive attitudes toward learning via mobile supplementary material. Mobile materials contribute positively to motivate them to learn English and increase their achievement scores.

Kee and Samsudin's (2014) study proves that female participants use their mobile devices in performing ubiquitous learning more than that of male participants. Moreover, the study of Leis, Tohei and Cooke (2015) proves that the use of smartphones increases intrinsic motivation to learn and developing their independence. Thus, since numerous studies proved students' negative attitudes toward writing and positive effect of mobile phones on improving students' attitudes to language learning, the present study is dedicated to use mobile phones to modify students' attitudes toward writing which consequently improves their writing skills.

\section{Method}

\subsection{Participants of the study}

The current research adopted the quasi- experimental design. The sample was selected at random from second grade preparatory school students and was divided into two groups: experimental and control. The attitudes of the two groups 
were measured using a pre-post attitude scale. The proposed program was offered to the experimental group in order to develop the participants' attitudes toward writing while the control group was taught via using regular method. The mean scores of the post test was analyzed to verify the impact of MALL approach on developing the students' attitudes toward writing.

\subsection{Hypotheses of the study:}

The current research attempts to verify the following hypotheses:

1-There is no statistical significant difference between the mean scores of the experimental group and control group students in the pre application of the attitude scale.

2- There is a statistically significant difference between the mean scores of the experimental group and control group students in the post application of the attitude scale test in favor of the former.

3-There is a statistically significant difference between the mean scores of the experimental group in the pre and post application of the attitude scale in favor of the latter.

4- The program has a positive effect on developing second year preparatory school students' attitudes toward writing.

\subsection{Instruments of the study}

In order to collect data related to the present study, the researchers constructed and applied a pre-post attitude scale. It aimed at identifying the attitudes of the two groups toward EFL writing before and after the implementation of the MALL program. It consisted of thirty nine (39) items. It was divided into four main domains: the first domain was about students' attitudes toward learning to write in English, the second one dealt with students' attitudes toward the value and importance of English writing, the third was concerned with students' attitudes toward the effect of English language teacher on writing; and the fourth domain concentrated on students' attitudes toward practising English writing. The items were constructed in a five-point Likert scale. For more detail, see table 1 .

To verify the validity of the scale, the researchers submitted it to a jury of ten specialists in TEFL as well as six specialists in educational psychology. The scale was modified according to their comments and suggestions. Also, the intrinsic validity of the scale was calculated as $(0.93)$. Thus, the attitude was likely to be valid for measuring students' attitudes toward writing. 
To establish the reliability of the scale, it was administered to a sample of thirty second-year preparatory grade students who were selected at random from Al Neel preparatory school for girls located in Damietta before experimentation. The researchers made use of Alpha Cronbach's Coefficient to calculate the reliability of the attitude scale which was (0.86).

Table 1

The Domains of the Attitude Scale

\begin{tabular}{|c|l|c|}
\hline No. & \multicolumn{1}{|c|}{ Domain } & Number of items \\
\hline 1 & Students' attitudes toward learning to write in English & 10 \\
\hline 2 & $\begin{array}{l}\text { Students' attitudes toward the value and importance of } \\
\text { English writing }\end{array}$ & 10 \\
\hline 3 & $\begin{array}{l}\text { Students' attitudes toward the effect of English language } \\
\text { teacher on writing }\end{array}$ & 8 \\
\hline 4 & Students' attitudes toward practising English writing & 11 \\
\hline
\end{tabular}

\subsection{The experiment:}

The field study started on November 15 and lasted for seven weeks till the end of the term. Before implementing the program on the experimental group, the researchers conducted the pre-writing attitude scale to determine the students' attitudes toward writing. Then, the researchers designed the proposed program on the basis of MALL approach along with a teachers' guide. The two groups were taught by two different teachers with the same educational background and experience. The experiment took place in two sessions per week. Each session was forty-five minutes. The program was compromised of fourteen sessions. In the first one, which lasted for a whole period (one hour and a half), the researchers conducted the pre application of the writing attitude scale. Then, in the second session, the students were informed that they were going to write using their mobile phones and they were taught how to write a paragraph. Then, in the rest of the sessions, the students had to perform writing tasks and activities via mobile. Moreover, after each five sessions, there was a revision session. Finally, the last session was devoted to the post application of tools.

Every writing session was composed of five stages. The first stage dealt with warm up, where the teacher provided a quick revision and/or quick introduction of what students were going to write about or with. Then, in the pre-writing stage, the students were required to gather and share ideas or words about the topic they were going to write about in groups through Whatsapp or Facebook groups either in class, or sometimes, at home. In writing stage, the students were supposed to use the ideas they collected to write down a paragraph or an e-mail on the note app. During the revising and editing stage, the students exchanged their written pieces 
either via Bluetooth or by exchanging the mobiles. Finally, they were asked to use a proofreading checklist to edit the written work. Also, at home, they sent their written products to their teacher to publish them on the Facebook group. The participants used android mobile phones of some brands likes Samsung, Alcatel, Huawei, Tecno, Sony, Motorola, Lenovo, Infinix and Oppo. They were required to use some of phone functionalities (dictionary, note app, Bluetooth, camera).

\section{Results:}

\subsection{Hypothesis one}

The first hypothesis states that: There is no statistical significant difference between the mean scores of the experimental group and control group students in the pre application of the attitude scale.

To verify this hypothesis, independent samples t-test was used to compare the difference between the mean scores of the experimental and control groups in the pre-administration of the writing attitude scale. Results are shown in the following table.

\section{Table 2}

Means, standard deviations and probability of the experimental and control groups' results in the pre-administration of the writing attitudes scale

\begin{tabular}{|c|c|c|c|c|c|c|}
\hline \multirow{2}{*}{ Domains } & \multirow{2}{*}{ Groups } & \multicolumn{5}{|c|}{ Independent Samples T-test } \\
\hline & & $\mathbf{N}$ & Mean & SD & $\mathbf{T}$ & P-value \\
\hline \multirow{2}{*}{$\begin{array}{l}\text { Students' attitudes toward learning } \\
\text { to write in English }\end{array}$} & Experimental group & 30 & 20.80 & 6.35 & \multirow{2}{*}{0.35} & \multirow{2}{*}{0.73} \\
\hline & Control group & 30 & 20.30 & 4.65 & & \\
\hline \multirow{2}{*}{$\begin{array}{l}\text { Students' attitudes toward the } \\
\text { value and importance of English } \\
\text { writing }\end{array}$} & Experimental group & 30 & 20.23 & 7.10 & \multirow{2}{*}{0.53} & \multirow{2}{*}{0.60} \\
\hline & Control group & 30 & 21.03 & 4.36 & & \\
\hline \multirow{2}{*}{$\begin{array}{l}\text { Students' attitudes toward the } \\
\text { effect of the English language } \\
\text { teacher on writing }\end{array}$} & Experimental group & 30 & 19.70 & 7.44 & \multirow{2}{*}{0.08} & \multirow{2}{*}{0.94} \\
\hline & Control group & 30 & 19.57 & 6.26 & & \\
\hline \multirow{2}{*}{$\begin{array}{l}\text { Students' attitudes toward } \\
\text { practising English writing }\end{array}$} & Experimental group & 30 & 20.97 & 4.92 & \multirow{2}{*}{0.58} & \multirow{2}{*}{0.56} \\
\hline & Control group & 30 & 19.97 & 8.03 & & \\
\hline \multirow{2}{*}{ The attitude toward writing } & Experimental group & 30 & 81.70 & 21.09 & \multirow{2}{*}{0.16} & \multirow{2}{*}{0.87} \\
\hline & Control group & 30 & 80.87 & 18.98 & & \\
\hline
\end{tabular}

Thus, the researchers could conclude the following results:

As for the first domain that is students attitudes toward learning to write in English, the mean scores of the experimental group in the pre-administration of the 
attitude scale was (20.80) and the standard deviation was (6.35) whereas the mean scores of the control group was (20.30) and the standard deviation was (4.65). In addition, the calculated t-value was $(0.35)$ whereas the P-value was $(0.73)$ which is higher than (0.05). Thus, it can be summed up that there was not any statistically difference between the two groups and thus there was homogeneity between the two groups in their attitudes toward learning to write in English.

Regarding the second domain about students' attitudes toward the value and importance of English, the mean scores of the experimental group in the pre administration of the attitude scale was(20.23) and the standard deviation was (7.10) whereas the mean scores of the control group was (21.03) and the standard deviation was (4.36). Also, the computed t-value was (0.53) and the P-value was (0.60) which is higher than $(0.05)$. Therefore, the results indicated that there was not any statistically difference between the two groups and thus there was homogeneity between the two groups in their attitudes toward the value and importance of English writing.

Concerning the third domain that is about students' attitudes toward the effect of the English language teacher on writing, the mean scores of the experimental group in the pre administration of the attitude scale was (19.70) and the standard deviation was (7.44) whereas the mean scores of the control group was (19.57) and the standard deviation was (6.26). Moreover, the estimated tvalue was (0.08) and the P-value was (0.94) which is higher than (0.05). Subsequently, this revealed that there was not any statistically difference between the two groups and thus there was homogeneity between the two groups in their attitudes toward the English language teacher.

Another domain is about students' attitudes toward practicing English writing. The mean scores of the experimental group in the pre-administration of the attitude scale was (20.97) and the standard deviation was (4.92) whereas the mean scores of the control group was (19.97) and the standard deviation was (8.03). Besides, the estimated t-value was (0.58) and the P-value was (0.56) which is higher than $(0.05)$. Hence, it was inferred that there was not any statistically difference between the two groups and thus there was homogeneity between the two groups in their attitudes toward practising English writing.

As for the overall writing attitude scale, the mean scores of the experimental group in the pre administration of the attitude scale was (81.70) and the standard deviation was (21.09) whereas the mean scores of the control group was (80.87) and the standard deviation was (18.98). Furthermore, the computed tvalue was $(0.16)$ and the P-value was $(0.87)$ which is higher than $(0.05)$. Thus, the results indicated that there was not any statistically difference between the two groups and thus there was homogeneity between the two groups in their overall attitudes toward writing. 


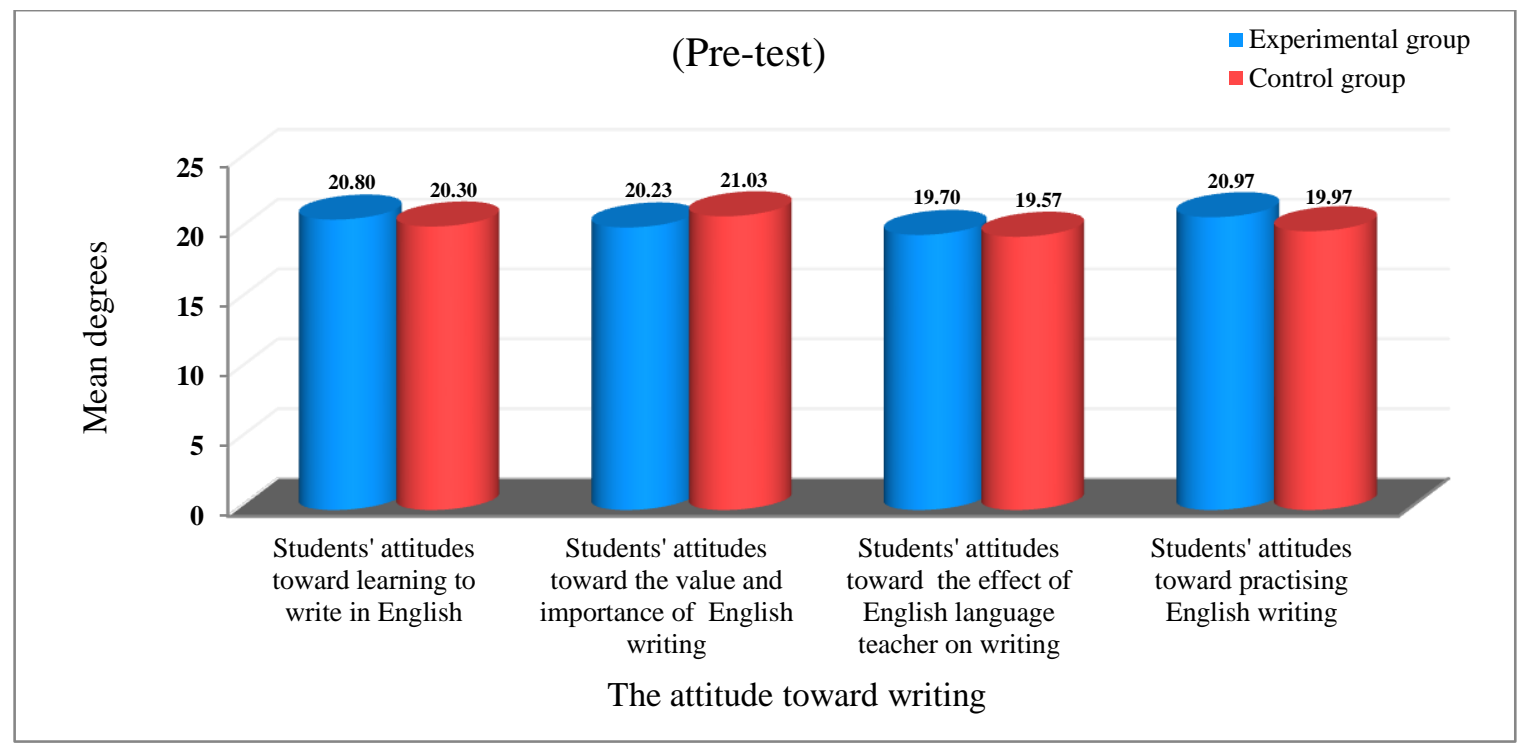

Figure 1

The mean scores of experimental and control groups in the pre- administration of each domain of the writing attitude scale

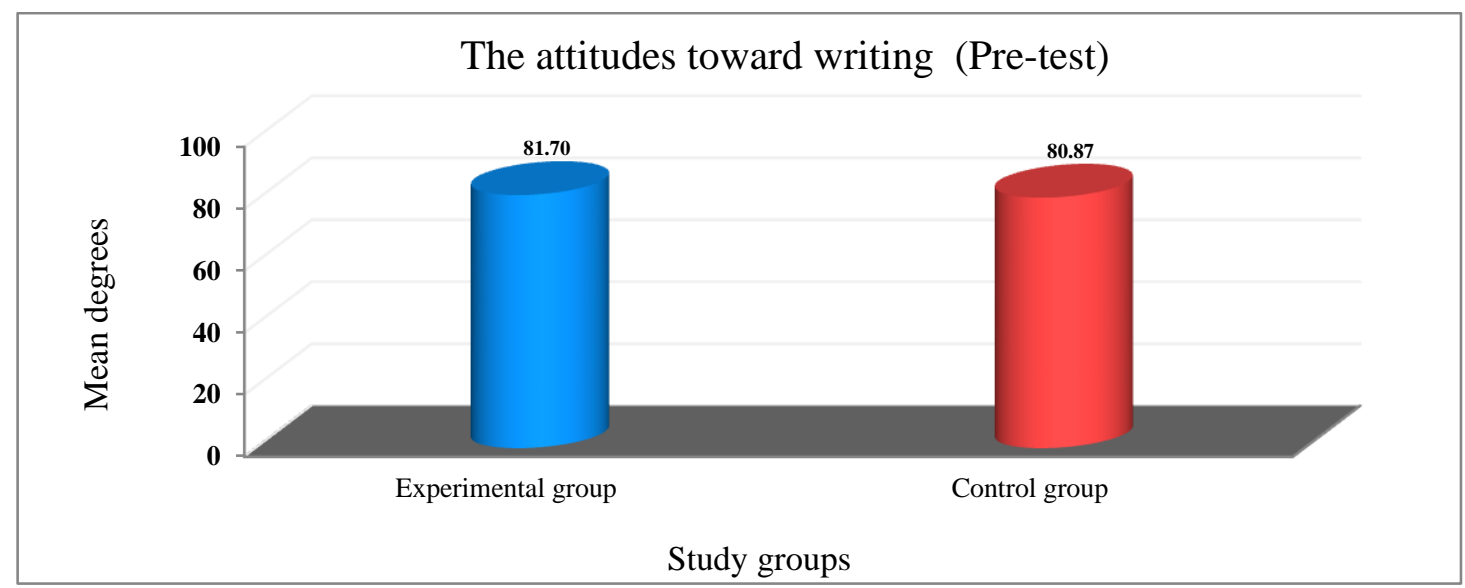

Figure 2

The mean scores of experimental and control groups in the pre- administration of overall writing attitude scale

From table 2 and its results as well as figures 1 and 2, it can be said that there was no statistical significant difference between the mean scores of the experimental group and the control group in the pre-administration of the attitude scale.

Findings of the first hypothesis demonstrate that there was no statistical significant difference between the mean scores of the experimental group and control group students in the pre administration of the attitude scale. There was obvious homogeneity between the two groups in the pre application of the attitude 
scale. This can be explained in the fact that the students of the two groups were homogenous since they were learning at similar governmental schools, having the same English course, learning from the same book and having similar learning experiences and environment. Moreover, they were taught through the same regular method. Also, their teachers had the same educational background. Therefore, any further difference between the two groups in the post application would be attributed to the effect of using the proposed program. Thus, the first hypothesis was clearly confirmed.

\subsection{Hypothesis Two}

The second hypothesis states that: There is a statistically significant difference between the mean scores of the experimental group and control group students in the post application of the attitude scale test in favor of the former.

To verify this hypothesis, independent samples t-test was used to compare between the experimental and control groups in the post-administration of the attitude scale toward writing and the results are shown in the following table.

Table 3

Means, standard deviations and probability of the experimental and control groups' results in the post-administration for the writing attitude scale

\begin{tabular}{|c|c|c|c|c|c|c|}
\hline \multirow{2}{*}{ Domains } & \multirow{2}{*}{ Groups } & \multicolumn{5}{|c|}{ Independent Samples T-test } \\
\hline & & $\mathbf{N}$ & Mean & SD & $\mathbf{T}$ & P-value \\
\hline \multirow{2}{*}{$\begin{array}{l}\text { Students' attitudes toward } \\
\text { learning to write in } \\
\text { English }\end{array}$} & Experimental group & 30 & 41.80 & 6.48 & \multirow{2}{*}{11.04} & \multirow{2}{*}{0.001} \\
\hline & Control group & 30 & 26.13 & 4.29 & & \\
\hline \multirow{2}{*}{$\begin{array}{l}\text { Students' attitudes toward } \\
\text { the value and importance } \\
\text { of English writing }\end{array}$} & Experimental group & 30 & 42.03 & 7.21 & \multirow{2}{*}{10.12} & \multirow{2}{*}{0.001} \\
\hline & Control group & 30 & 25.83 & 4.99 & & \\
\hline \multirow{2}{*}{$\begin{array}{l}\text { Students' attitudes toward } \\
\text { the effect of the English } \\
\text { language teacher on } \\
\text { writing }\end{array}$} & Experimental group & 30 & 31.27 & 7.79 & \multirow[b]{2}{*}{4.29} & \multirow[b]{2}{*}{0.001} \\
\hline & Control group & 30 & 23.33 & 6.47 & & \\
\hline \multirow{2}{*}{$\begin{array}{l}\text { Students' attitudes toward } \\
\text { practising English writing }\end{array}$} & Experimental group & 30 & 39.73 & 8.44 & \multirow{2}{*}{6.94} & \multirow{2}{*}{0.001} \\
\hline & Control group & 30 & 25.77 & 7.08 & & \\
\hline \multirow{2}{*}{ The attitude toward writing } & Experimental group & 30 & 154.83 & 24.03 & \multirow{2}{*}{9.38} & \multirow{2}{*}{0.001} \\
\hline & Control group & 30 & 101.07 & 20.19 & & \\
\hline
\end{tabular}


The researchers could conclude the following results:

As for the domain about students' attitudes toward learning to write in English, the mean scores of the experimental group in the post administration of the attitude scale was (41.80) and the standard deviation was (6.48) whereas the mean scores of the control group was (26.13) and the standard deviation was (4.29). Besides, the estimated t-value was (11.04) and the P-value was (0.001) which is less than (0.05). Thus, this result revealed that there was statistically significant difference between the two groups in students' attitudes toward learning to write in English in favor of the experimental group.

Concerning the other domain about students' attitudes toward the value and importance of English writing, the mean scores of the experimental group in the post administration of the attitude scale was (42.03) and the standard deviation was (7.21) whereas the mean scores of the control group was (25.83) and the standard deviation was (4.99). Also, the estimated t-value was (10.12) and the P-value was (0.001) which is less than (0.05). Consequently, it was deduced that there was statistically significant difference between the two groups in students' attitudes toward the value and importance of English writing in favor of the experimental group.

Regarding the other domain about students' attitudes toward the effect of the English language teacher on writing, the mean scores of the experimental group in the post administration of the attitude scale was (31.27) and the standard deviation was (7.79) whereas the mean scores of the control group was (23.33) and the standard deviation was (6.47). Moreover, the calculated t-value was (4.29) and the P-value was $(0.001)$ which is less than $(0.05)$. Hence, this indicates that there was statistically significant difference between the two groups in students' attitudes toward the English language teacher in favor of the experimental group.

Relating the domain about students' attitudes toward practising English writing, the mean scores of the experimental group in the post administration of the attitude scale was (39.73) and the standard deviation was (8.44) whereas the mean scores of the control group was (25.77) and the standard deviation was (7.08). In addition, the estimated t-value was (6.94) and the P-value was (0.001) which is less than (0.05). Therefore, it was assumed that there was statistically significant difference between the two groups in students' attitudes toward practising English writing in favor of the experimental group.

For the overall attitude toward writing, the mean scores of the experimental group in the post-administration of the attitude scale was (154.83) and the standard deviation was (24.03) whereas the mean scores of the control group was (101.07) and the standard deviation was (20.19). Besides, the estimated $\mathrm{t}$-value was (9.38) and the P-value was (0.001) which is less than (0.05). As a result, it was summed up that there was statistically significant difference between 
the two groups in students' overall attitudes toward English writing in favor of the experimental group.

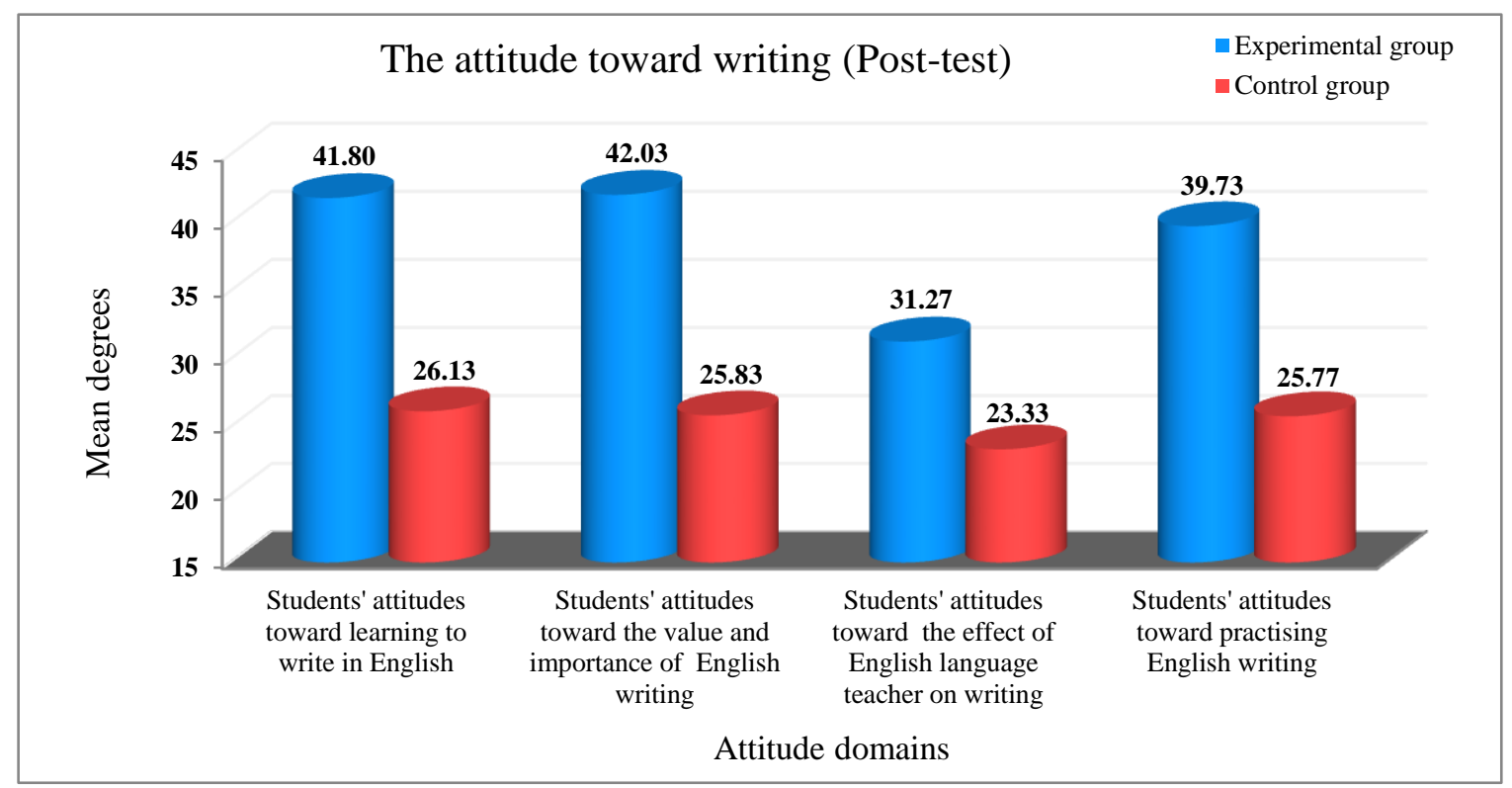

\section{Figure 2}

The mean scores of the experimental and control groups in the domains of the attitude scale in the post-administration

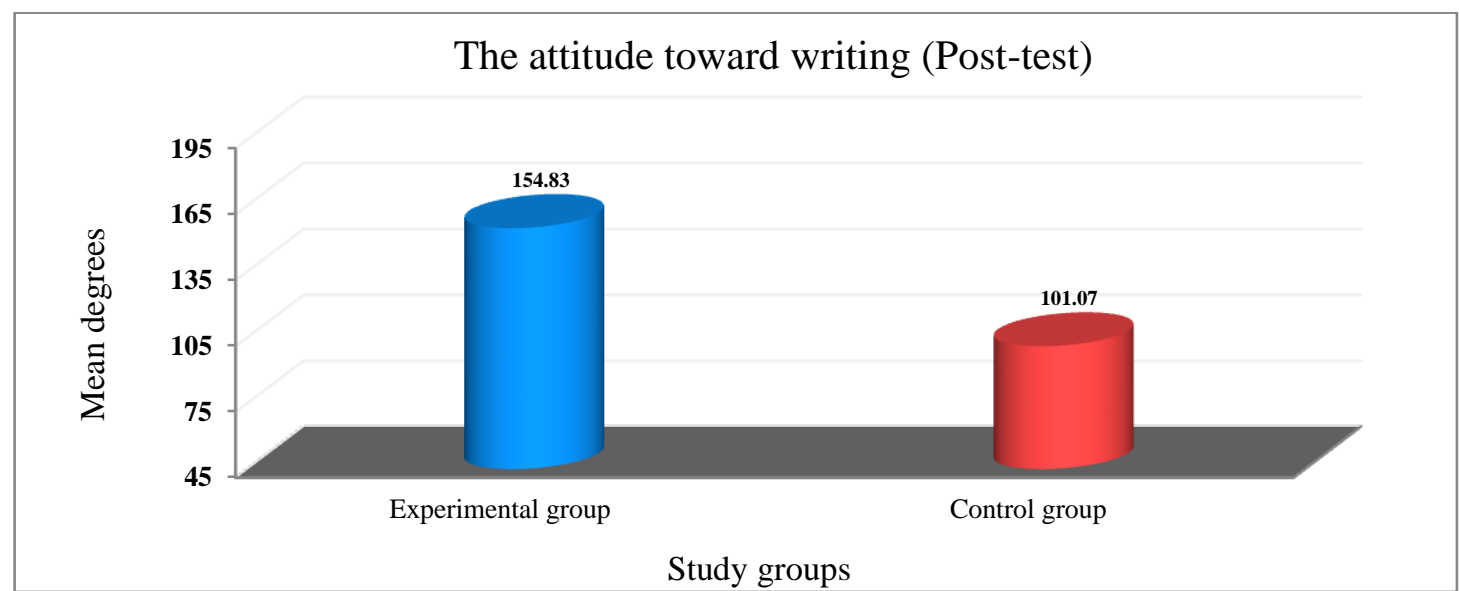

\section{Figure 4}

The mean overall scores of the experimental and control groups in the post administration of the writing attitude scale

Results of table 3 and figures 3 and 4 indicate that there was a statistically significant difference at $\leq 0.05$ between the mean scores of the experimental and control groups in the post administration of the attitude scale test in favor of the former. Thus, this result shows that the second hypothesis was accepted. 


\subsection{Hypothesis three}

The third hypothesis states that: There is a statistically significant difference $\leq 0.05$ between the mean scores of the experimental group in the pre and post application of the attitude scale in favor of the latter.

To verify this hypothesis, Paired Samples T-test was used to compare between the experimental group pre and post administrations of the writing attitude scale and the results are shown in the following table.

\section{Table 4}

Means, standard deviations and probability of the experimental and control groups' results in the pre and post administrations of the writing attitude scale

\begin{tabular}{|c|c|c|c|c|c|c|}
\hline \multirow{2}{*}{ Domains } & \multirow{2}{*}{ Groups } & \multicolumn{5}{|c|}{ Paired Samples T-test } \\
\hline & & $\mathbf{N}$ & Mean & SD & $\mathbf{T}$ & P-value \\
\hline \multirow{2}{*}{$\begin{array}{l}\text { Students' attitudes toward } \\
\text { learning to write in } \\
\text { English }\end{array}$} & Post-test & \multirow{2}{*}{30} & 41.80 & 6.48 & \multirow{2}{*}{12.25} & \multirow{2}{*}{0.001} \\
\hline & Pre-test & & 20.80 & 6.35 & & \\
\hline \multirow{2}{*}{$\begin{array}{l}\text { Students' attitudes toward } \\
\text { the value and importance } \\
\text { of English writing }\end{array}$} & Post-test & \multirow[t]{2}{*}{30} & 42.03 & 7.21 & \multirow[t]{2}{*}{13.54} & \multirow[t]{2}{*}{0.001} \\
\hline & Pre-test & & 20.23 & 7.10 & & \\
\hline \multirow{2}{*}{$\begin{array}{l}\text { Students' attitudes toward } \\
\text { the effect of the English } \\
\text { language teacher on } \\
\text { writing }\end{array}$} & Post-test & \multirow[b]{2}{*}{30} & 31.27 & 7.79 & \multirow[b]{2}{*}{9.60} & \multirow[b]{2}{*}{0.001} \\
\hline & Pre-test & & 19.70 & 7.44 & & \\
\hline \multirow{2}{*}{$\begin{array}{l}\text { Students' attitudes toward } \\
\text { practising English writing }\end{array}$} & Post-test & \multirow{2}{*}{30} & 39.73 & 8.44 & \multirow{2}{*}{13.39} & \multirow{2}{*}{0.001} \\
\hline & Pre-test & & 20.97 & 4.92 & & \\
\hline \multirow{2}{*}{$\begin{array}{l}\text { The attitude toward } \\
\text { writing (All) }\end{array}$} & Post-test & \multirow{2}{*}{30} & 154.83 & 24.03 & \multirow{2}{*}{16.51} & \multirow{2}{*}{0.001} \\
\hline & Pre-test & & 81.70 & 21.09 & & \\
\hline
\end{tabular}

The researchers could assume the following points:

Regarding this domain about students' attitudes toward learning to write in English, the mean scores of the experimental group in the post administration was (41.80) and the standard deviation was (6.48) whereas the mean scores of the pre test was (20.80) and the standard deviation was (6.35). The calculated t-value was (12.25) and the P-value was (0.001) which was less than (0.05). It can be deduced that there is a statistically significant difference between the pre and post administration in students' attitudes toward learning to write in English in favor of the post administration. 
Concerning the domain about students' attitudes toward the value and importance of English writing, the mean scores of the experimental group in the post administration was (42.03) and the standard deviation was (7.21) whereas the mean scores of the pre test was (20.23) and the standard deviation was (7.10). The estimated t-value was (13.54) and the P-value was (0.001) which is less than (0.05). Thus, this result asserts that there is a statistically significant difference between the pre and post administration in students' attitudes toward the value and importance of English writing in favor of the post administration.

As for the other domain about students' attitudes toward the effect of the English language teacher on writing, the mean scores of the experimental group in the post administration was (31.27) and the standard deviation was (7.79) whereas the mean scores of the pre test was (19.70) and the standard deviation was (7.44). The computed t-value was (9.60) and the P-value was (0.001) which is less than (0.05). Consequently, this result reveals that there is a statistically significant difference between the pre and post administration in students' attitudes toward the English language teacher in favor of the post administration.

With regard to the last domain about students' attitudes toward practising English writing, the mean scores of the experimental group in the post administration was (39.73) and the standard deviation was (8.44), whereas the mean scores of the pre test was (20.97) and the standard deviation was (4.92). Also, the estimated t-value was (13.39) and the P-value was (0.001) which is less than (0.05). Hence, this result indicates that there is a statistically significant difference between the pre and post administration in students' attitudes toward practising English writing in favor of the post administration.

Regarding the overall writing attitude scale, the mean scores of the experimental group in the post administration was (154.83) and the standard deviation was (24.03), whereas the mean scores of the pre test was (81.70) and the standard deviation was (21.09). The estimated t-value was (9.38) and the P-value was (0.001) which is less than (0.05). Accordingly, there is a statistically significant difference between the pre and post administration in students' attitudes toward writing in favor of the post administration. 


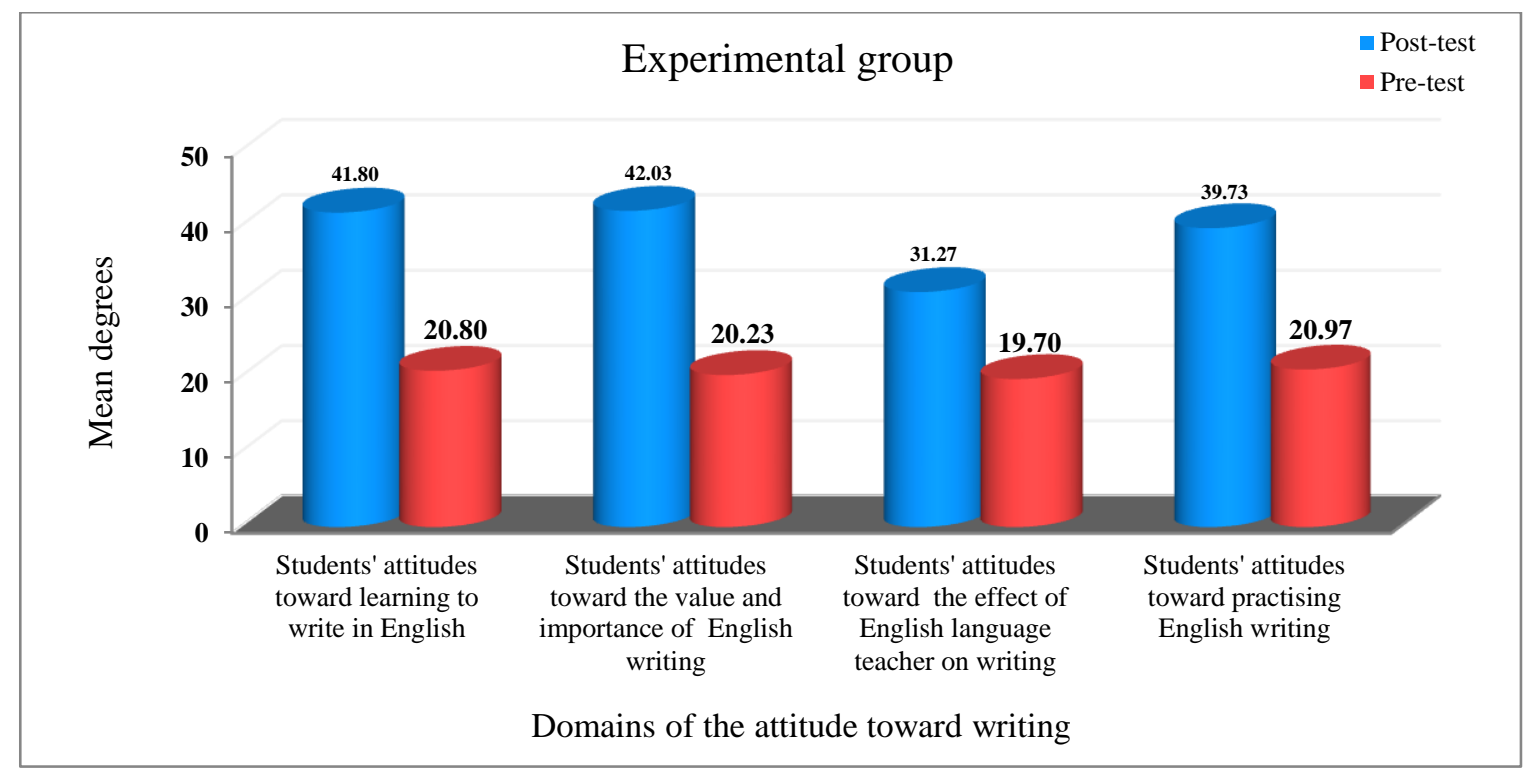

Figure 5

The mean scores of the experimental group students in the pre and post administration of writing attitude domains

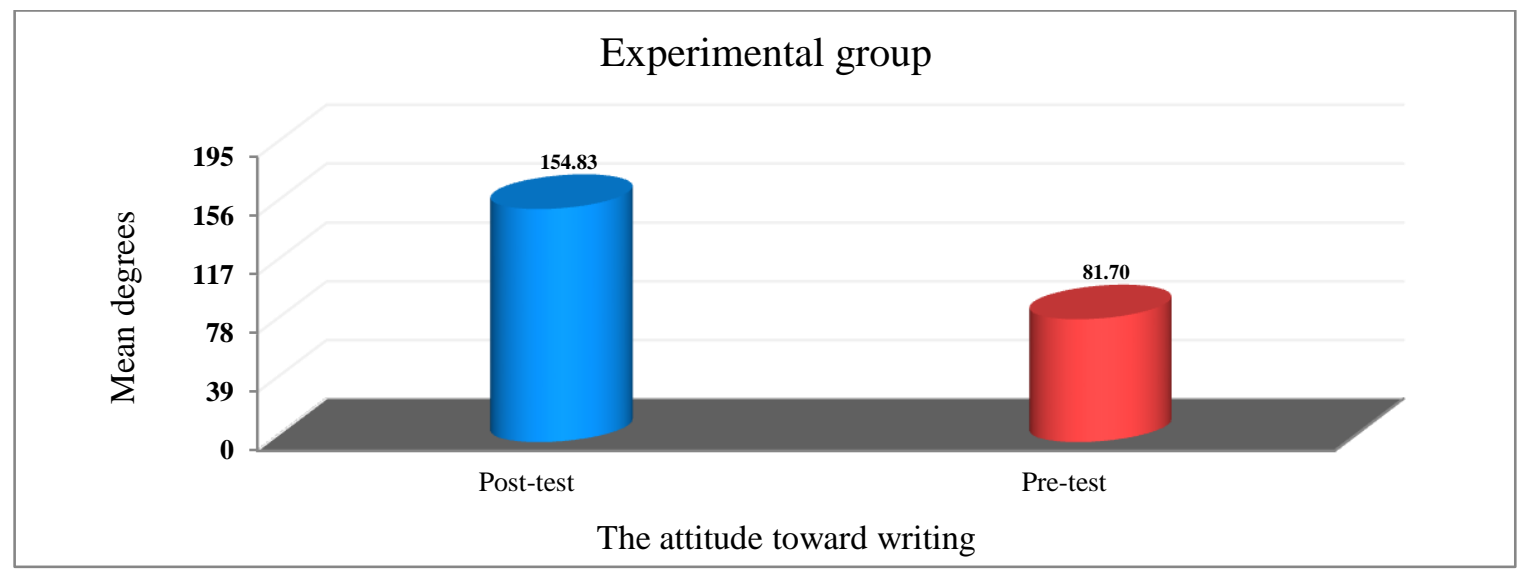

\section{Figure 6}

The mean overall scores of the experimental group in the pre and post administration of the writing attitude scale

Table 4 with its results and figures 5 and 6 prove that there is a statistically significant difference between the mean scores of the experimental group in the pre and post administration of the attitude scale in favor of the post one. Therefore, the sixth hypothesis was accepted.

\subsection{Hypothesis four}

The fourth hypothesis states that: The program has a positive effect on developing second-year preparatory school students' attitudes toward writing. 
To verify this hypothesis, eta square equation was used and the results are shown in the following table.

\section{Table 5}

The effect size (df), t-value and eta-square results' of MALL program on developing experimental group's writing attitudes

\begin{tabular}{|l|c|c|c|}
\hline Domains & df & T & Eta square \\
\hline $\begin{array}{l}\text { Students' attitudes toward } \\
\text { learning to write in English }\end{array}$ & 29 & 12.25 & 0.84 \\
\hline $\begin{array}{l}\text { Students' attitudes toward the } \\
\text { value and importance of English } \\
\text { writing }\end{array}$ & 29 & 13.54 & 0.86 \\
\hline $\begin{array}{l}\text { Students' attitudes toward the } \\
\text { effect of the English language } \\
\text { teacher on writing }\end{array}$ & 29 & 9.60 & 0.76 \\
\hline $\begin{array}{l}\text { Students' attitudes toward } \\
\text { practising English writing }\end{array}$ & 29 & 13.39 & 0.86 \\
\hline The attitudes toward writing & 29 & 16.51 & 0.90 \\
\hline
\end{tabular}

Table (19) reveals the following points:

As for the domain students' attitudes toward learning to write in English, Eta square level was (0.84). The ratio of complete contrast of experimental group students' attitudes toward learning to write in English which can be attributed to the effect of MALL program which the researcher used is $(84.0 \%)$.

Regarding the domain about students' attitudes toward the value and importance of English writing, Eta square level was (0.86). The ratio of complete contrast of experimental group students' attitudes toward the value and importance of English writing which can be attributed to the effect of MALL program which the researcher used is $(86.0 \%)$.

Concerning the domain students' attitudes toward the effect of the English language teacher on writing, Eta square level was (0.76). The ratio of complete contrast of experimental group students' attitudes toward the English language Teacher which can be attributed to the effect of MALL program which the researcher used is $(76.0 \%)$.

For the last domain about students' attitudes toward practising English writing, Eta square level was (0.86). The ratio of complete contrast of 
experimental group students' attitudes toward practising English writing which can be attributed to the effect of MALL program which the researcher used is $(86.0 \%)$.

Relating the overall attitude scale toward writing, Eta square level was (0.90). The ratio of complete contrast of experimental group students' attitudes toward writing which can be attributed to the effect of MALL program which the researcher used is $(90.0 \%)$.

These results assert the large effect of the MALL program on developing the experimental group students' attitudes toward writing.

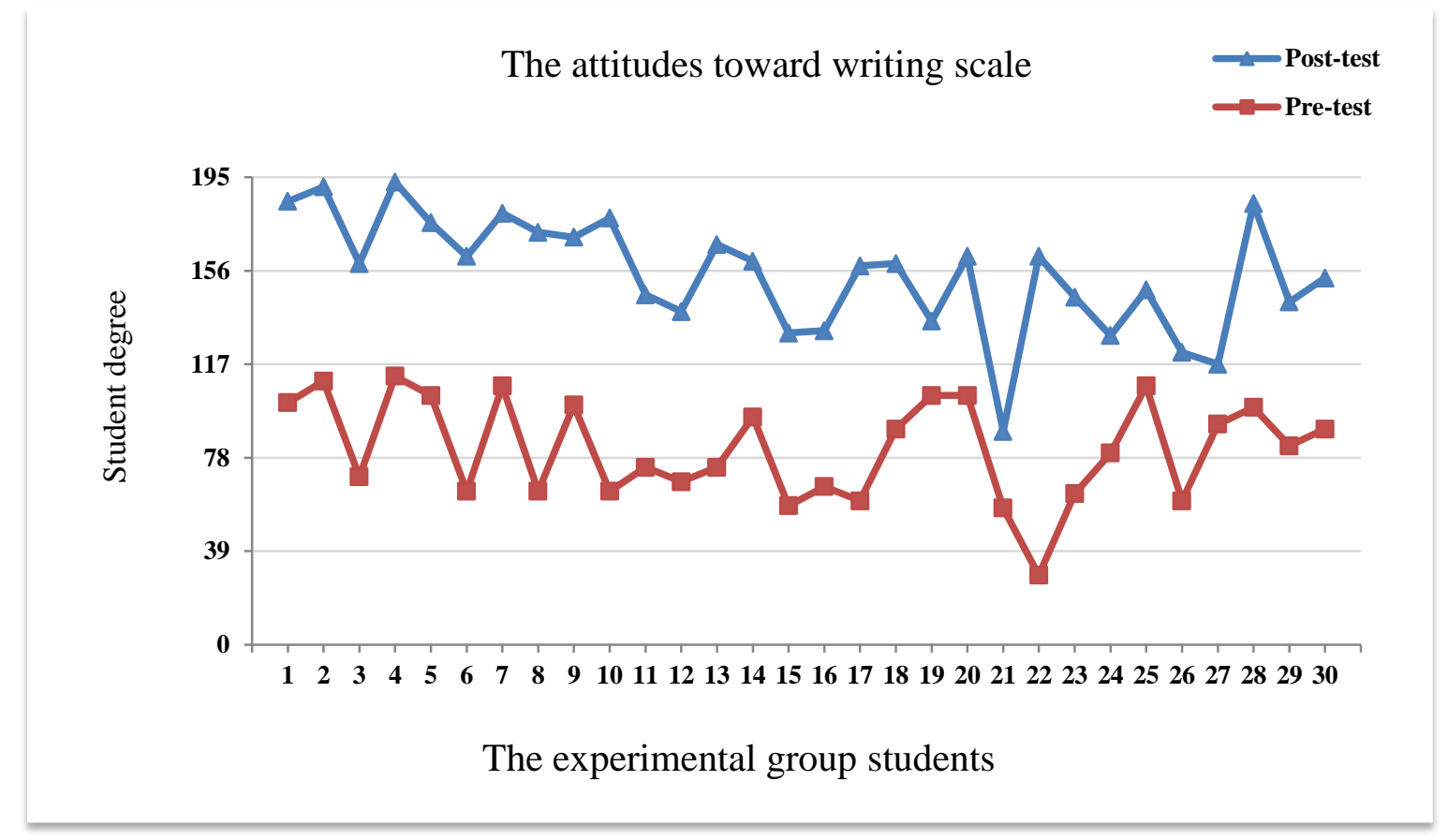

Figure 7

The effect of the MALL program on developing students' writing attitudes

\section{Discussion and conclusion}

Findings of the present study indicate that there was a statistically significant difference at $\leq 0.05$ between the mean scores of the experimental group and control group students in the post administration of the attitude scale in favor of the former. It means that the program was effective in developing the students' attitudes toward the four domains of the scale. It is noted that third domain was the least domain to be affected by the program. It could be said that the teacher does not have a considerable role concerning the students' attitudes toward writing. Furthermore, the greatest influence of the program was on the second domain. Thus, when the students use mobile phones, they realized the importance of 
English language as a language of worldwide communication and a language of most mobile applications.

It was found out that using the program had a great effect on developing the students' positive attitudes toward writing. This can be interpreted as Gajalakshmi (2013) and Ibnian (2012) stated that providing numerous opportunities and activities for students to use language in expressing their opinions and ideas in an EFL class can help them develop their attitudes toward language learning. Moreover, this can be attributed to the idea that states that students have positive attitudes toward integrating mobile phones in language learning. Also, research (e.g. Chen, Chang and Yen, 2012; Hashemi, Azizinezhad, Najafi and Nesari, 2011; Kim and Kwon, 2012; Kukulska-Hulme, 2006; Miangah and Nezarat, 2012) illustrated that mobile phones help increase motivation toward learning as they make learning enjoyable experiences by providing multimedia tools. Korkmaz's (2010) and Lin (2010) stated that integrating mobile phone into learning English, as a favorable medium to learners; being handy and ubiquitous, help in motivating students to learn English, make learning more fun, and increase students' achievement.

The results agree with the studies of Hassan and Nasiri (2014) which proved students' positive attitude toward mobile phones as an interesting way for learning a language. Also, the results are consistent with the studies of Al Amari (2011), Al Fahd (2009) Cavus and Ibrahim's study (2009), Ibrahim (2012), Korkmaz (2010) and Shanmugapriya and Tamilarasi (2013) which asserted that students enjoy using mobile phones in learning English in general. Also, the study of Cui and Wang (2008) recommended the integration of cellular phones in education because of their characteristics as well as their positive influence on students' attitudes toward English learning.

Moreover, there was a statistically significant difference between the mean scores of the experimental group in the pre and post administration of the attitude scale in favor of the latter. One of the advantages of using mobile phones is that they motivated the students to learn English. They enjoyed using them in learning to allow ubiquitous learning. The use of mobile in learning help students increase their positive attitudes toward learning and write in English because it (a) provides multiple activities; (b) deals with students' learning preferences; (c) is a source of attractive multimedia; (d) breaks the routine of regular academic tasks; and (e) coincides with contemporary innovations pleasing learners of the new generation. These results agree with the study of Leis, Tohei, and Cooke (2015) which proved that the use of smartphones increases intrinsic motivation to learn and developing students' independence. Also, these results are consistent with the findings of the studies of Al Amari (2011), Lu (2008) and Suwantarathip and Orawiwatnakul 
(2015) which proved that phones would be effective tools as they increase learners' motivation to learn English.

Therefore, when the students became motivated to write, this affected their writing practice. Abidin, Mohammadi and Alzwari (2012) as well as Karahan (2007) asserted that high motivation and positive attitude of students facilitate second language learning and influence their performance in acquiring the target language. Thus, if a learner has the interest and desire to acquire the target language, he/she will be motivated and enthusiastic in language learning. Consequently, this interprets the development of the students' attitudes toward practising English writing.

Results of the present study proved that the proposed program, which is based on MALL approach, is successful in developing second year preparatory school students' attitudes toward writing. This is reflected in the post administration of the writing attitude scale. Using MALL approach motivates learners to write. Moreover, MALL was proved to be effective in engaging the students in collaborative work.

Findings of the present study have some implications on incorporating smart phones in teaching English in general and writing skill in particular. The present study proves that the use of mobile phones has a considerable positive effect on developing English writing skills. As mobile assisted language learning transgress time and place limitations, learners can make use of their mobile phones to learn anywhere; in transport, while waiting at the public places or even at schools. Moreover, the study asserts that the use of mobile phones in learning can develop learners' positive attitudes. Students like to use their phones nearly most of their time to call their friends, text them or contact with them online through social media sites. Therefore, students' tendencies and preferences must be considered in order to enhance and facilitate their learning.

To sum up, the current study has proven a considerable positive effect of mobile phones on developing English writing skills. It is clear that employing mobile phones in language learning needs acceptance, enthusiasm, collaboration and support from all stakeholders as well as all educational practitioners. First, learners may be directed to accept using mobile phones not merely as a playing tool, but also as a vehicle to develop their attitudes toward writing. Teachers need to be trained on how to integrate and use mobile phones and other mobile technologies in their teaching. Moreover, curriculum designers and course developers are required to identify the fundamentals as well as the problems of applying mobile assisted language learning approach in the educational context to get the most benefit. 


\section{References}

Abbasi, M. \& Hashemi, M. (2013). The impact/s of Using Mobile Phone on English Language Vocabulary Retention. International Research Journal of Applied and Basic Sciences, 4(3), 541-547.

Abidin, M \& Alzwari, H. (2012). EFL Students' Attitudes towards Learning English Language: The Case of Libyan Secondary School Students. Asian Social Science, 8(2), 119-134.

Abu Sa'aleek, A. (2014). A review of emerging technologies: Mobile assisted language learning. Asian Journal of Education and E-Learning, 2(6), 469-475.

Alemi, M., Sarab, M. \& Lari, Z. (2012). Successful learning of academic word list via MALL: Mobile- Assisted language learning. International Education studies, 5(6), 99-109.

Al- Fahd, F. (2009). Students' attitudes and perceptions towards the effectiveness of mobile learning in King Suad University. The Turkish online journal of educational technology, 8(2), 50-58.

Ally, M., \& McGreal, R., \& Schafer, S., \& Tin, T., \& Cheung, B. (2007). Use of Mobile Learning Technology to Train ESL Adults. Proceedings of the Sixth International Conference on Mobile Learning, Melbourne.

Alsayed, M. (2014). The Effect of a WebQuest Program on Developing First year Preparatory Stage Students' English Writing Skills and their Attitudes Towards Writing. Unpublished master's thesis. Faculty of Education, Fayoum University.

Alzu'bi, M. \& Sabha, M. (2013). Using Mobile-Based Email for English Foreign Language Learners. TOJET: The Turkish Online Journal of Educational Technology, 12(1), 178-186.

Averianova, I. (2012). A cell phone in the classroom: A friend or a foe? Proceedings of the EUROCALL 2011 Conference, 20, 5-12.

Aydin, S. \& Başoz, T. (2010). The Attitudes of Pre-service Teachers towards EFL Writing. Journal of Language and Linguistic Studies, 6(2), 5-69.

Azar, A. \& Nasiri, H. (2014). Learners' Attitudes toward the Effectiveness of Mobile Assisted Language Learning (MALL) in L2 Listening Comprehension. Procedia - Social and Behavioral Sciences, 98, 1836 - 1843. 
Baleghizadeh, S. \& Oladrostam, E. (2010). The Effect of Mobile Assisted Language Learning (MALL) on Grammatical Accuracy of EFL Students. MEXTESOL Journal, 34 (2), 1-10.

Berking, J. \& Haag, P. (2015). A Reference Model for Designing Mobile Learning and Performance Support. Paper presented at the Interservice/Industry Training, Simulation and Education Conference, Orlando, Florida, 30 November - 4 December.

Cavus, N. \& Ibrahim, D. (2009). M learning: An experiment in using sms to support learning new English language words. British Journal of educational Technology, 40(1), 78-91.

Chen, I., Chang, C. \& Yen, J. (2012). Effects of presentation mode on mobile language learning: A performance efficiency perspective. Australasian Journal of Educational Technology, 28(1), 122-137.

Clark, C. \& Dugdale, G. (2009). Young People's writing: Attitudes, behaviour and the role of technology. London: National literacy trust

Cote, T., Milliner, B., Flowers, S. \& Ferreira, D. (2014). What's going on at the MALL? Perspectives, 12, 37-40.

Cui, G. \& Wang, S. (2008). Adopting cell phones in EFL teaching and learning. Journal of educational technology development and exchange, 1(1), 69-80.

Elashri, I. (2013). The effect of the genre-based approach to teaching writing on the EFL al Azhar secondary students' writing skills and their attitudes towards writing. Eric Document Reproduction Service ED539137.

Erarslan, A. (2011). Perceptions and Attitudes of the Preparatory Class Students towards the Writing Course and Attitude-Success Relationship in Writing in the School of Foreign Languages at Pamukkale University. Unpublished master's thesis, Pamukkale University, Turkey.

Gajalakshmi, K. (2013). High school students' attitude towards leaning English language. International Journal of Scientific and Research Publications, 3(9), 1-7.

Gholami, J. \& Azarmi, G. (2012). An introduction to Mobile Assisted Language Learning. International Journal of Management, IT and Engineering, 2 (8), 1-9. 
Hammam, D. (2017). A Mobile Assisted Language Learning Program (MALL) for Developing Some Speaking Skills of First Year Secondary Students in Alexandria. Unpublished master's thesis, Institute of Educational studies, Cairo University.

Hashemi, M., Azizinezhad, M., Najafi, V. \& Nesari, A. (2011). What is Mobile Learning ? Challenges and Capabilities. Procedia - Social and Behavioral Sciences $30,2477-2481$.

$\mathrm{Hu}$, Z. (2011). Vocabulary learning Assisted by mobile phones: perceptions of Chinese adult learners. Journal of Cambridge studies, 8(1), 139-154.

Ibnian, S. (2012). Group Work and Attitudes of Non-English Major Students towards Leaning EFL. International Journal of Humanities and Social Science, 2(4), 192-197.

Ibrahim, M. (2012). The effectiveness of educational situations based on moving and static technologies in developing second kindergarten college students' achievement and attitudes toward their use in education. Technology of pedagogy journal "studies and researches", 14, 117-163.

Ismail, N., Hussin, S. \& Darus, S. (2012). ESL Students' Attitude, Learning Problems, And Needs For Online Writing. GEMA Online ${ }^{\mathrm{TM}}$ Journal of Language Studies, 12(4), 1089- 1107.

Karahan, F. (2007). Language attitudes of Turkish students towards the English language and its use in Turkish context. Journal of Arts and Sciences, 7, 73-87.

Kee. C. \& Samsudin, Z. (2014). Mobile devices: toys or learning tools for the 21st century teenagers? TOJET: The Turkish Online Journal of Educational Technology, 13 (3), 107-122.

Kennedy, C. \& Levy, M. (2008). L'italiano al telefonino: Using SMS to support beginners' language learning. European Association for Computer Assisted Language Learning, 20(3), 315-330.

Khabiri, M. \& Khatibi, M. (2013). Mobile Assisted Language Learning: practices among Iranian EFL learners. European Online journal of natural and social sciences, 2(2), 176-190.

Kim, H. \& Kwon, Y. (2012). Exploring Smartphone Applications for Effective Mobile-Assisted Language Learning. Multimedia Assisted language learning, 15(1), 31-57. 
Korkmaz, H. (2010). THE effectiveness of mobile assisted language learning as a supplementary material for english language teaching coursebooks. Unpublished master's thesis, Bilkent University, Ankara.

Kotula, A., Tivnan, T. \& Aguilar, C. (2014). Students' Voices: The Relationship between Attitudes and Writing Outcomes for Fourth and Fifth Graders. Waltham: Education Development Center, Inc.

Kukulska-Hulme, A. (2009). Will mobile phone learning change learning? Recall, 2(2), 157-16.

Kukulska-Hulme, A. (2006). Mobile language learning now and in the future. In P. Svensson (ed.), From Vision to practice: language learning and IT (pp. 295310). Sweden: Swedish Net University.

Kukulska-Hulme, A. \& Shield, L. (2008). An overview of mobile assisted language learning: From content delivery to supported collaboration and interaction. ReCALL, 20(3), 271-289.

Leis, A., Tohei, A., \& Cooke, S. D. (2015). Smartphone Assisted Language Learning and Autonomy. International Journal of Computer-Assisted Language Learning and Teaching (IJCALLT), 5(3), 75-88.

Lin, Y. (2010). The prospect of learning English via mobile phones for junior high school students in Taiwan. Proceedings of the 2010 Conference on English Learning, National Pingtung University of Education, 188-209.

Lu, M. (2008). Effectiveness of vocabulary learning via mobile phone. Journal of Computer Assisted Learning, 24, 515-525.

Ma'rouf, S., \& Nasser, Y. (2010). Students' attitudes toward English and its relation to achievement among genders in the light of prevailing class management Patterns (a field study on a sample from Damascus private and official schools' first secondary school students). Damascus university journal, 26(2), 739- 771.

Miangah, T. \& and Nezarat, A. (2012). Mobile-Assisted Language Learning. International Journal of Distributed and Parallel Systems (IJDPS), 3(.1), 309-319. 
Moghaddam, M. \& Mousavi, M. (2012). Utilizing cell phones in language learning: from idea to practice. Paper presented at the first conference on language learning and teaching: interdisciplinary approach, Mashhad, Iran, 30-31 October.

National Council for curriculum and Assessment (2007). Mobile Assisted language learning. Report on the pilot study.

Oz, H. (2015). An Investigation of Preservice English Teachers' Perceptions of Mobile Assisted Language Learning. English Language Teaching, 8(2), 82-34.

Penaflorida, A. (2002). Non traditional forms of assessment and response to student writing: A step toward learner autonomy. In J. Richards \& W. Renandya (eds.), Methodology in language teaching: An Anthology of current practice (pp.344-353). New York: Cambridge University Press.

Pilar, R., Jorge, A. \& Cristina, C. (2013). The Use of Current Mobile Learning Applications in EFL. Procedia : Social and Behavioral Sciences, 103, 1189 1196.

Purcell, K., Buchanan, J. \& Friedrich, L. (2013). The Impact of Digital Tools on Student Writing and How Writing is taught in Schools. Retrieved September 20, 2015 from http://pewinternet.org/Reports/2013/Teachers-technology-and-writing. Saed, H. \& AL-Omari, H. (2014). The Effectiveness of a Proposed Program Based on a Mind Mapping Strategy in Developing the Writing Achievement of Eleventh Grade EFL Students in Jordan and Their Attitudes towards Writing. Journal of Education and Practice, 5(18), 88-109.

Salama, G. \& Al-Ashiri, I. (2012). The Effect of A training Program for Arabic and English Teachers in Al-Azhar Based on the First Package of the Project Zero in Egypt on the Students' Writing Performance. Eric Document Reproduction Service ED542280.

Saran, M., Seferoglu, G. \& Cagiltay, K. (2008). Mobile Assisted Language Learning: English Pronunciation at Learners' Fingertips. Eurasian Journal of Educational Research, 34, 1-18.

Shanmugapriya, M. \& Tamilarasi, A. (2013). Design and Development of Mobile Assisted Language Learning (MALL) application for English Language using Android Push Notification Services. International Journal of Research in Computer and Communication Technology, 2(6), 329-338. 
Sirinat, K., Sirorat, P., Suriya, C. \& Thooptong, K. (2014). The Use of Text Messages in Mobile Phones for Enhancing English Writing Skill (Special issue). Journal of Education, Mahasarakham University, 720-727.

Suwantarathip, O. \& Orawiwatnakul, W. (2015). Using mobile-assisted exercises to support students' vocabulary skill development. TOJET: The Turkish Online Journal of Educational Technology, 14 (1), 163-171.

Tayebinik, M. \& Puteh, M. (2012). Mobile Learning to Support Teaching English as a Second Language. Journal of Education and Practice, 3(7), 56-62.

Thornton, P. \& Houser, C. (2005). Using mobile phones in English Education in Japan. Journal of computer assisted learning, 21, 217-228.

Yedla, S. (2013). MALL (Mobile Assisted Language Learning): A Paradise for English Language Learners. International Journal of English Language \& Translation Studies, 1(2), 91-99. 


\section{Appendix \\ The Attitude Scale toward Writing}

\begin{tabular}{|c|c|c|c|c|c|c|}
\hline & Statements & 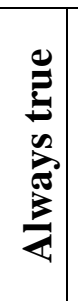 & 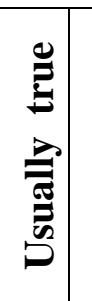 & 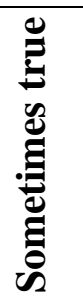 & 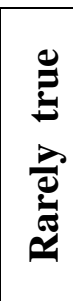 & 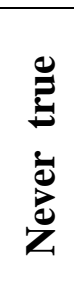 \\
\hline \multicolumn{7}{|c|}{ A. Students' attitudes toward learning to write in English: } \\
\hline 1 & I like to acquire new writing skills in English. & & & & & \\
\hline 2 & $\begin{array}{l}\text { I expect to write any topic in English after I finish this } \\
\text { school year. }\end{array}$ & & & & & \\
\hline 3 & $\begin{array}{l}\text { I willingly follow instructions that I learn from my } \\
\text { teacher when doing my writing homework. }\end{array}$ & & & & & \\
\hline 4 & $\begin{array}{l}\text { I listen attentively when there is a class related to } \\
\text { learning English writing skills. }\end{array}$ & & & & & \\
\hline 5 & $\begin{array}{l}\text { I think it is impossible to learn English without studying } \\
\text { writing skills. }\end{array}$ & & & & & \\
\hline 6 & I learn writing skills easily. & & & & & \\
\hline 7 & I feel proud when I write anything in English. & & & & & \\
\hline 8 & $\begin{array}{l}\text { I think that the study of writing skills adds a lot to my } \\
\text { English language proficiency. }\end{array}$ & & & & & \\
\hline 9 & I feel happy when I miss any English writing classes. & & & & & \\
\hline 10 & I feel happy learning to write in English. & & & & & \\
\hline \multicolumn{7}{|c|}{ B. Students' attitudes toward the value and importance of English writing: } \\
\hline 1 & $\begin{array}{l}\text { I like learning to write to communicate with others } \\
\text { worldwide. }\end{array}$ & & & & & \\
\hline 2 & $\begin{array}{l}\text { I think that practicing writing helps me pass my } \\
\text { examinations. }\end{array}$ & & & & & \\
\hline 3 & $\begin{array}{l}\text { I wish that writing activities be lessened in the school } \\
\text { syllabus. }\end{array}$ & & & & & \\
\hline 4 & $\begin{array}{l}\text { I think that practicing writing in English is time } \\
\text { consuming. }\end{array}$ & & & & & \\
\hline 5 & $\begin{array}{l}\text { I wish that English writing classes could be increased in } \\
\text { the school schedule. }\end{array}$ & & & & & \\
\hline 6 & Writing in English is important to my future career. & & & & & \\
\hline 7 & $\begin{array}{l}\text { I feel that learning to write is more valuable than other } \\
\text { writing with other languages. }\end{array}$ & & & & & \\
\hline
\end{tabular}




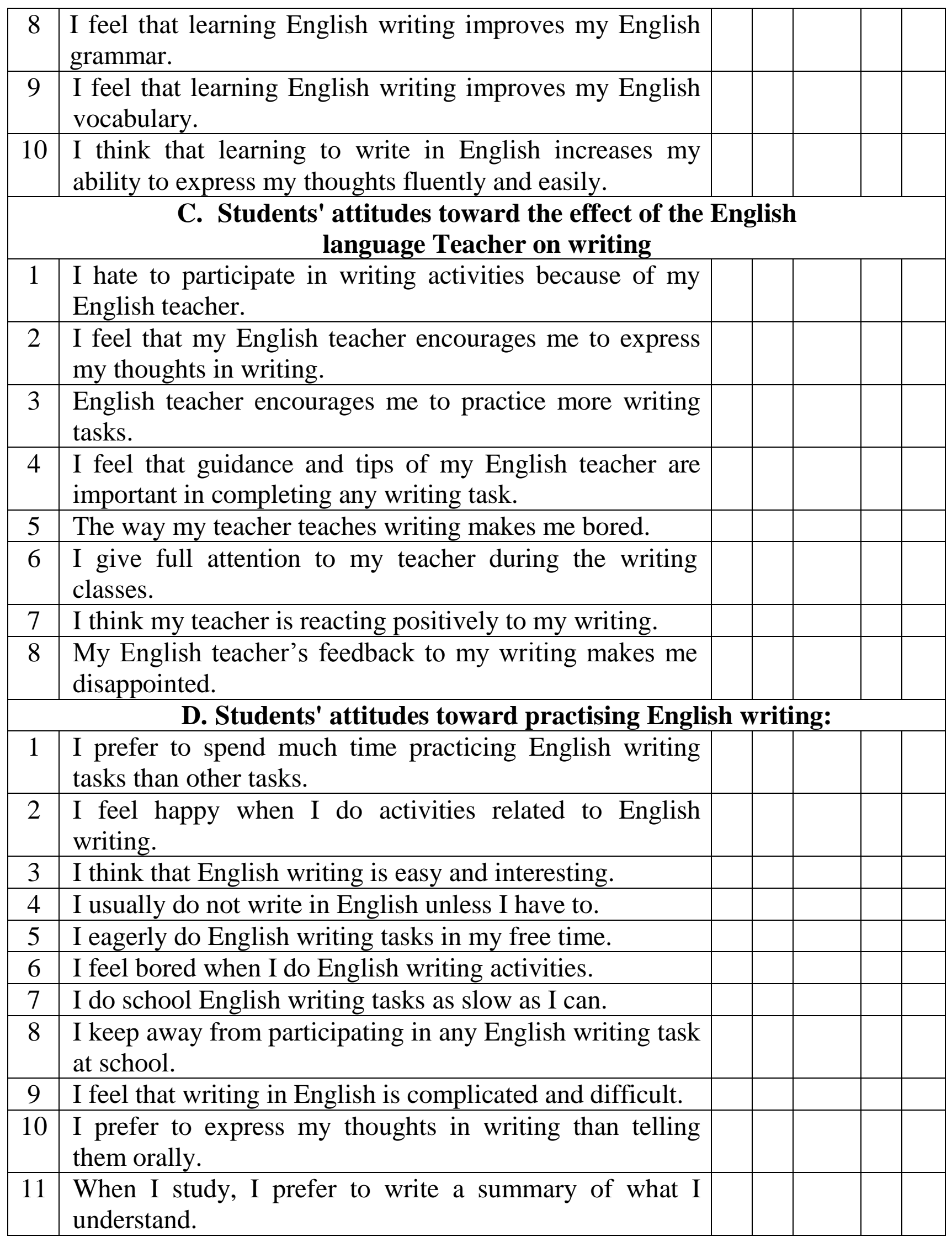

